
rock with the use of remote instrumentation of «Search»

*M. Kovalyov, S. Soldatova, V. Gokh, (Sevastopol National University of Nuclear Energy and Industry)

\title{
SUMMARY
}

Analyzing the results of the practical search operations using means of distance exploration for the detection and delineation of gas anomalies in shale rocks, determining the amount of gas horizons, their depth and power of gas pressure in them, as well as the migration routes of natural gas in shale formations. In the survey area (128 km2, the southern part of Texas, USA) found that gas anomalies occur not in all area of shale rock, and only in certain regions with increased fracturing of rocks (identified 25 anomalies, each area of $0.1 \mathrm{~km} 2$ to $3.1 \mathrm{~km} 2$, the total area was $7.2 \mathrm{~km} 2$ ). Gas accumulations occur in the 6 horizons at depths from $800 \mathrm{~m}$ to $2500 \mathrm{~m}$, capacity of each horizon is $60 \mathrm{~m}$, and the gas pressure in them is distributed evenly within 55-60 atm. Field geophysical studies have confirmed that all anomalies are interconnected by narrow (15-20 m wide) collectors in the fractured rocks with two major gas deposits, which have gas pressure $600 \mathrm{~atm}$. and located near the licensed area at a distance of 1,5-2,0 km depth 3,5-3,65 km. Drilling has established that these gas fields (gas pressure $620 \mathrm{~atm}$., The total area of $7.24 \mathrm{~km} 2$ and gas-bearing collector $150 \mathrm{~m}$ ) are more promising for the development than any anomalies in shale rocks that are suitable for development. These features of the occurrence of gas anomalies in shale rocks revealed by the equipment "Search» allows a more efficient organization of search operations and significantly improve the economic performance of developing shale gas fields.

\section{Дослідження особливостей залягання газових аномалій у сланцевих породах з застосуванням апаратури дистанційного комплексу «Пошук»}

*М. І. Ковалев, С.В. Солдатова, В.А. Гох, (Севастопольський національний університет ядерної енергї і промисловості)

\section{РЕЗЮМЕ}

Аналізуючи результати практичних пошукових робіт із застосуванням дистанційних засобів геологорозвідки з виявлення та оконтурювання газових аномалій у сланцевих породах, визначення кількості газових горизонтів, їх потужностей глибин залягання і тиску газу в них, а також шляхів міграції газу в сланцевих породах. На обстежуваній площі (128 км2, південна частина штату Техас, США) встановлено, що газові аномалії залягають не по всій площі сланцевих порід, а тільки на окремих ділянках з підвищеною тріщинуватістю порід (виявлено 25 аномалій, площа кожної від 0,1 км2 до 3,1 км2, їх загальна площа склала 7,2 км2). Газові скупчення залягають в 6 горизонтах на глибинах від 800 м до 2500 м, потужність кожного горизонту становила 60 м, а тиск газу в них розподілено рівномірно в межах 55-60 атм. Польові геофізичні роботи підтвердили, що всі аномалії з'єднані між собою вузькими (15-20 м шириною) колекторами із тріщинуватих порід з двома великими газовими покладами, що 
мають тиск газу 600 атм. і розташованими поблизу ліцензійної площі на відстані 1,5-2,0 км на глибинах залягання 3,5-3,65 км. Буріння встановило, що дані газові поклади (з тиском газу 620 атм., загальною площею 7,24 км2 і газоносним колектором 150 м) є більш перспективними для розробки, ніж всі аномалії в сланцевих породах, придатних для розробки. Зазначені особливості залягання газових аномалій у сланцевих породах, виявлені за допомогою апаратури «Пошук» дозволяють більш ефективно організувати пошукові роботи й істотно підвищити економічні показники освоєння сланцевих газових родовищ.

\section{Исследование особенностей залегания газовых аномалий в} сланцевых породах с применением аппаратуры дистанционного комплекса «Поиск»

*Н. И. Ковалев, С.В. Солдатова, В.А. Гох, (Севастопольский национальный университет ядерной энергии и промыпиленности)

\section{РЕЗЮМЕ}

Анализируя результаты практических поисковых работ с применением дистанционных средств геологоразведки по обнаружению и оконтуриванию газовых аномалий в сланцевых породах, определения количества газовых горизонтов, их мощностей глубин залегания и давления газа в них, а также путей миграции газа в сланцевых породах.

На обследуемой площади (128 км2, южная часть штата Техас, США) установлено, что газовые аномалии залегают не по всей площади сланцевых пород, а только на отдельных участках с повышенной трещиноватостью пород (выявлено 25 аномалий, площадь каждой от 0,1 км2 до 3,1 км2, их общая площадь составила 7,2 км2). Газовые скопления залегают в 6 горизонтах на глубинах от 800 м до 2500 м, мощность каждого горизонта составляла 60 м, а давление газа в них распределено равномерно в пределах 55-60 атм.

Полевые геофизические работы подтвердили, что все аномалии соединены между собой узкими (15-20 м шириной) коллекторами по трещиноватым породам с двумя крупными газовыми залежами, имеющими давление газа 600 атм. и расположенными вблизи лицензионной площади на расстоянии 1,5-2,0 км на глубинах залегания 3,5-3,65 км. Бурение установило, что данные газовые залежи (с давлением газа 620 атм., общей площадью 7,24 км2 и газоносным коллектором 150 м) являются более перспективными для разработки, чем все аномалии в сланцевых породах, пригодные для разработки.

Указанные особенности залегания газовых аномалий в сланцевых породах, выявленные с помощью аппаратуры «Поиск» позволяют более эффективно организовать поисковые работы и существенно повысить экономические показатели освоения сланцевых газовых месторождений. 
Анализируя результаты практических поисковых работ с применением дистанционных средств геологоразведки по обнаружению и оконтуриванию газовых аномалий в сланцевых породах, определения количества газовых горизонтов, их мощностей глубин залегания и давления газа в них, а также путей миграции газа в сланцевых породах.

На обследуемой площади (128 км², южная часть штата Техас, США) установлено, что газовые аномалии залегают не по всей площади сланцевых пород, а только на отдельных участках с повышенной трещиноватостью пород (выявлено 25 аномалий, площадь каждой от 0,1 км $^{2}$ до $3,1 \mathrm{kм}^{2}$, их общая площадь составила 7,2 км²). Газовые скопления залегают в 6 горизонтах на глубинах от 800 м до 2500 м, мощности каждого горизонта составляли $\sim 60$ м, а давление газа в них распределено равномерно в пределах 55-60 атм.

Полевые геофизические работы подтвердили, что все аномалии соединены между собой узкими (15-20 м шириной) коллекторами по трещиноватым породам с двумя крупными газовыми залежами, имеющими давление газа 600 атм. и расположенными вблизи лицензионной площади на расстоянии 1,5-2,0 км на глубинах залегания 3,5-3,65 км. Бурение установило, что данные газовые залежи (с давлением газа 620 атм., общей площадью 7,24 км ${ }^{2}$ и газоносным коллектором 150 м) являются более перспективными для разработки, чем все аномалии в сланцевых породах, пригодные для разработки.

Указанные особенности залегания газовых аномалий в сланцевых породах, выявленные с помощью аппаратуры «Поиск» позволяют более эффективно организовать поисковые работы и существенно повысить экономические показатели освоения сланцевых газовых месторождений. 